\title{
Total phenolic content, free radical scavenging capacity, and anti- cancer activity of silymarin
}

\author{
Uyory Choe $^{\mathrm{a}}$, Monica Whent ${ }^{\mathrm{a}}$, Yinghua Luo ${ }^{\mathrm{b}}$ and Liangli Yu ${ }^{\mathrm{a}}$ \\ aDepartment of Nutrition and Food Science, University of Maryland, College Park, MD 20742, USA \\ ${ }^{b}$ College of Food Science and Engineering, National Engineering Research Center for Fruit and Vegetable Processing, Ministry of Educa- \\ tion, China Agricultural University, Beijing, China \\ *Corresponding author: Monica Whent, Department of Nutrition and Food Science, University of Maryland, College Park, MD 20742, \\ USA. Tel: +1 301 4054521; E-mail: mwhent@umd.edu \\ DOI: $10.31665 /$ JFB.2020.10227 \\ Received: June 19, 2020; Revised received \& accepted: June 29, 2020 \\ Citation: Choe, U., Whent, M., Luo, Y., and Yu, L. (2020). Total phenolic content, free radical scavenging capacity, and anti-cancer activity \\ of silymarin. J. Food Bioact. 10: 53-63.
}

\begin{abstract}
Milk thistle (Silybum marianum) seeds are a good source of dietary polyphenols. The bioactive component of milk thistle seeds, silymarin, contains flavonolignans including silybin $A$, silybin $B$, isosilybin $A$, isosilybin $B$, silychristin, isosilychristin, and silydiain along with the flavonol taxifolin. Silymarin is used traditionally as a natural herbal medicine with minimal side effects. Structurally, each silymarin component possesses phenolic hydroxyl groups and thus works as an antioxidant. In addition to free radical scavenging capacities, silymarin's anti-cancer activities were reported for many different types of cancers including bladder, breast, colon, gastric, kidney, lung, oral, ovarian, prostate, and skin. The current review will discuss silymarin's chemical components, total phenolic content, free radical scavenging capacities, and anti-cancer activities.
\end{abstract}

Keywords: Milk thistle; Silymarin; Flavonolignan; Polyphenols; Antioxidant; Cancer.

\section{Introduction}

Silymarin is a mixture of flavonolignans found in milk thistle (Silybum marianum) seeds. Silymarin has been used since ancient times due to its hepatoprotective effects (Flora et al., 1998). An ancienct Greek pharmacologist and botanist, Dioscorides, noted that tea of milk thistle seeds could cure the bite of a poisonous snake (Flora et al., 1998). Milk thistle seeds' hepatoprotective effects have been extensively studied. Currently silymarin is widely used as a dietary supplement for the treatment of liver-related diseases such as jaundice, cirrhosis, liver cancer, and fatty liver disease (Federico et al., 2017). In addition, silymarin possesses free radical scavenging capacity and anti-cancer activity. However, compared to hepatoprotective effects, silymarin's free radical scavenging capacities and anti-cancer activities have not been thoroughly reviewed.

A free radical is an unpaired electron found in reactive oxygen species (ROS) such as superoxide $\left(\mathrm{O}_{2}{ }^{-}\right)$and the hydroxyl radical $\left({ }^{\circ} \mathrm{OH}\right)$. ROS can cause damage to lipids, protein, and DNA, known as oxidative stress. Oxidative stress can trigger pro-inflammatory responses and inflammation is associated with many chronic diseases such as Alzheimer's disease, diabetes, cardiovascular disease, inflammatory disorders, asthma, and cancers (Willcox et al., 2010). Therefore, dietary antioxidants may reduce the risk of chronic diseases by quenching free radicals.

Well-known dietary antioxidants include vitamins A, C, and E. Additionally, polyphenolic compounds found in fruits, vegetables, and herbs can work as antioxidants and play an important role in free radical scavenging. In general, polyphenolic content is positively correlated with the free radical scavenging capacity of a plant extract. However, free radical scavenging capacity is not always directly proportional to total phenolic content. Antioxidants in plants may have capacity to quench various types of free radicals. Therefore, to have a better understanding and idea of the health beneficial effects of polyphenolic compounds, measuring both total phenolic content and free radical scavenging capacity is necessary.

Another important health benefit of polyphenolic compounds 


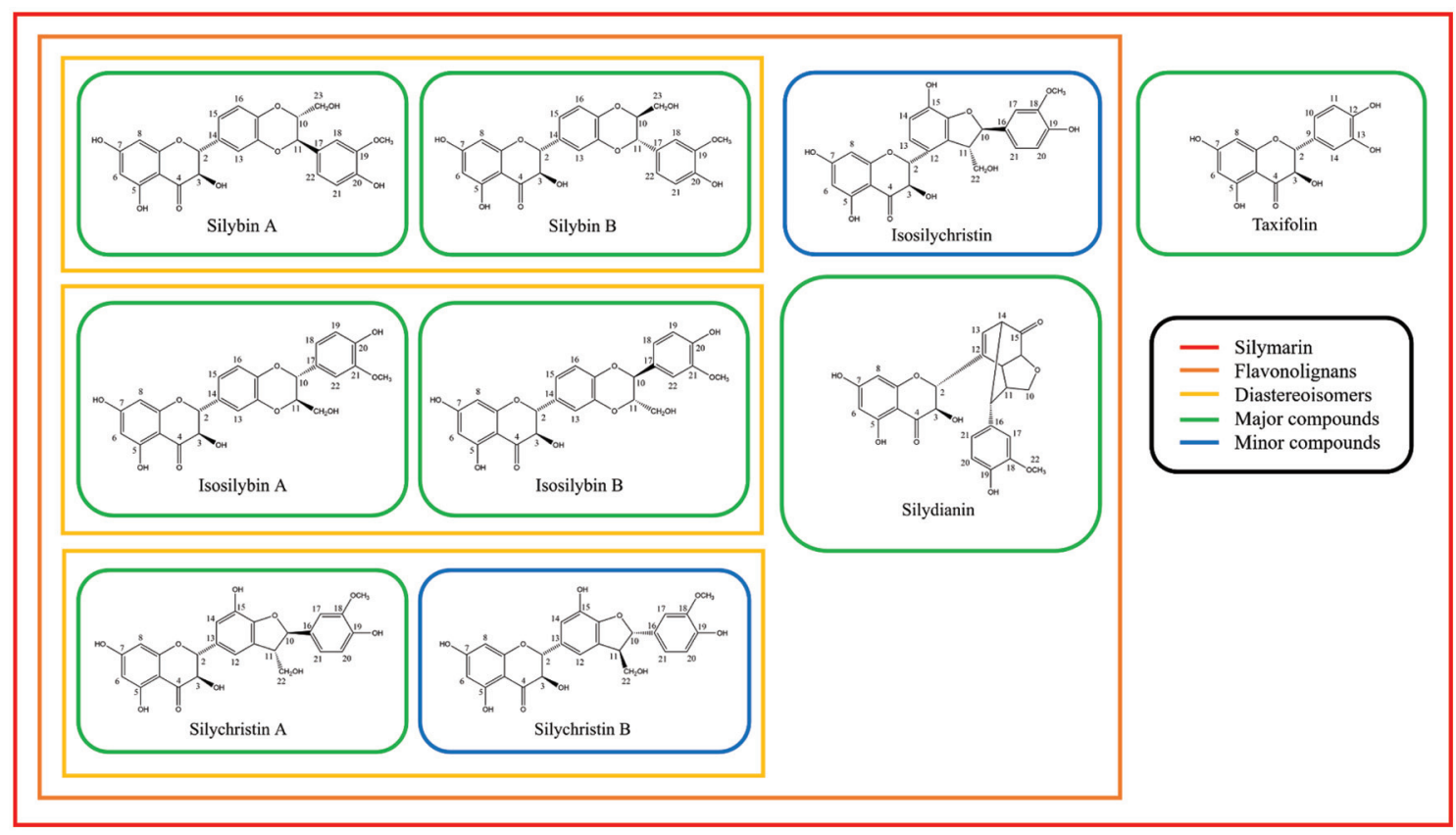

Figure 1. Chemical components of silymarin and their chemical structures.

is anti-cancer activity. Throughout diverse biochemical processes, polyphenolic compounds can modulate pathways involved in carcinogenesis. This is mainly due to the chemical structure of polyphenolic compounds. Polyphenolic compounds possess a number of phenolic hydroxyl groups. These phenolic hydroxyl groups can quench free radicals and possibly block or suppress oxidative stress that causing cancer. Cancer is the second highest cause of death in the world and associated with oxidative stress. More than 9 million people in the world died as a result of cancer in 2018 (World Health Organization, 2018). According to the National Institutes of Health, estimated national expenditures for cancer care in the United States in 2017 were $\$ 147.3$ billion (National Institutes of Health, 2020). Prevention of cancer with dietary components, particularly polyphenols, has often been studied. Silymarin is a mixture of polyphenolic compounds that possess strong antioxidant and anti-cancer activity with minimal physiological side effects. Hence, silymarin may be used in nutraceutical and functional foods targeting oxidative stress and cancer. This review will discuss silymarin's chemical components, total phenolic content, free radical scavenging capacity, and anti-cancer activity.

\section{Chemical components of silymarin}

Silymarin is composed of flavonolignans and taxifolin (Fig. 1). Flavonolignans include silybin A, silybin B, isosilybin A, isosilybin $\mathrm{B}$, silychristin $\mathrm{A}$, silychristin $\mathrm{B}$, isosilychristin, and silydianin. These flavonolignans are isomers and have the same molecular weight and chemical formula of $482 \mathrm{~g} / \mathrm{mol}$ and $\mathrm{C}_{25} \mathrm{H}_{22} \mathrm{O}_{10}$, respectively (Lee and Liu, 2003). Taxifolin belongs to a flavanonol which is a subclass of flavonoids and silymarin flavonolignans are derived from taxifolin (AbouZid and Ahmed, 2013). Among flavonolignans, six flavonolignans including silybin A, silybin B, isosilybin $\mathrm{A}$, isosilybin $\mathrm{B}$, silychristin $\mathrm{A}$, and silydianin are the major flavonolignans found in silymarin. The other flavonolignans, Silyhristin B and isosilychristin, are the minor compounds (Fig. 1).
Silymarin accounts for about 70 to $80 \%$ of milk thistle seed extract and the remaining components are other polyphenols and fatty acids (Karimi et al., 2011). The composition of silymarin varies depending on milk thistle's cultivar, growing condition, harvesting stage, and extraction methods. For example, in 2006, Martin and others extracted silymarin from German and New Zealand milk thistle seeds using the Soxhlet apparatus and ethyl acetate as the solvent and evaluated chemical compositions. In German milk thistle, the total silymarin content was $6 \mathrm{~g} / \mathrm{kg}$ of milk thistle while the New Zealand milk thistle had silymarin content of $18 \mathrm{~g} / \mathrm{kg}$. The primary component of silymarin from German milk thistle was silybin B followed by silychristin A (18.2\%) silydianin (17.6\%), silybin A (16\%), isosilybin A (12.2\%), isosilybin B (6.7\%), and silychristin B (4.8\%). For the New Zealand silymarin composition, the primary component was silybin B $(36.8 \%)$ followed by silybin A $(24.1 \%)$, silychristin A $(23.7 \%)$, isosilybin A (8.6\%), silychristin B (4.4\%), and isosilybin B (2.3\%) (Martin et al., 2006). It is noted that the total silymarin content and composition from German and New Zealand's milk thistle seeds were different. Previously, our group extracted milk thistle seed flour using 50\% acetone as a solvent and evaluated its chemical composition. The primary component was silychristin followed by silybin B, isosilybin A and B, and silybin A (Choe et al., 2019). The primary component of both silymarins from German and New Zealand milk thistle seeds was silybin B (Martin et al., 2006). However, the primary component found in our previous study was silychristin. As mentioned earlier, this difference in chemical compositions may due to variation in milk thistle cultivar, growing condition, harvesting stage, and extraction methods.

The primary component of silymarin found in Martin's study, silybin $\mathrm{B}$, is often regarded as a primary component of silymarin. Together with silybin B's diastereomer, silybin A, the mixture is called silibinin (Fig. 1). Both silybin A and B have five hydroxyl groups (3-OH, 5-OH, 7-OH, 20-OH, and 23-OH). Among them, three hydroxyl groups, $5-\mathrm{OH}, 7-\mathrm{OH}$, and $20-\mathrm{OH}$ possess a phenolic nature (Bijak, 2017). The number of phenolic hydroxyl 
groups is directly related to the free radical scavenging capacities (Chen et al., 2020). For solubility, the silibinin is soluble in polar solvents such as ethanol, methanol, dimethyl sulfoxide (DMSO), acetone, and dimethylformamide (DMF) but not very soluble in water (Biedermann et al., 2014).

Similar to silibinin, the 1:1 ratio mixture of isosilybin A and B are often called isosilibinin. Isosilibinin has the same molecular weight and formula as silibinin which is $482 \mathrm{~g} / \mathrm{mol}$ and $\mathrm{C}_{25} \mathrm{H}_{22} \mathrm{O}_{10}$, respectively. The hydroxyl groups of isosilybin $\mathrm{A}$ and $\mathrm{B}$ are located at the same positions as silybin $\mathrm{A}$ and $\mathrm{B}$ which are at $\mathrm{C}_{3}, \mathrm{C}_{5}, \mathrm{C}_{7}$, $\mathrm{C}_{20}$, and $\mathrm{C}_{23}(3-\mathrm{OH}, 5-\mathrm{OH}, 7-\mathrm{OH}, 20-\mathrm{OH}$, and 23-OH). The difference between silibinin and isosilibinin is the $\mathrm{R}$ group attached to $\mathrm{C}_{10}$ and $\mathrm{C}_{11}$. In silybinin, the hydroxymethyl group is attached to $\mathrm{C}_{10}$, and 2-methoxyphenol is attached to $\mathrm{C}_{11}$. Isosilybinin has a hydroxymethyl group in its $\mathrm{C}_{11}$ and 2-methoxyphenol in $\mathrm{C}_{10}$ positions (Fig. 1).

Silychristin also has diastereomers A and B. However, unlike silibinin and isosilibinin, the mixture of silychristin A and B's ratio is not 1:1 and does not have a name for its mixture. Silychristin A makes up $95 \%$ of the mixture and only $5 \%$ is silychristin B. Silychristin $\mathrm{A}$ and $\mathrm{B}$ have six hydroxyl groups and they are located at $\mathrm{C}_{3}, \mathrm{C}_{5}, \mathrm{C}_{7}, \mathrm{C}_{19}$, and $\mathrm{C}_{22}$ (3-OH, 5-OH, 7-OH, 15-OH, 19-OH, and 22-OH) (Fig. 1).

Isosilychristin has a very similar structure to silychristin. The $\mathrm{R}$ group attached to $\mathrm{C}_{2}$ is the same for silychristin and isosilychristin. The only difference is its connected position. For silychristin, the $\mathrm{R}$ group is connected through $\mathrm{C}_{2}$ and $\mathrm{C}_{13}$ while isosilychristin's $\mathrm{R}$ group is connected through $\mathrm{C} 2$ and $\mathrm{C}_{12}$ (Fig. 1).

Silydianin is one of the major components of silymarin and accounts for about $5-10 \%$ of silymarin (Chambers et al., 2017). Silydianin is structurally the most complex and has a distinctive structure compared to other flavonolignans found in silymarin. The structural complexity of silydianin comes from the bicyclic structure with the keto group which is attached to the $\mathrm{C}_{2}$ position (Fig. 1). Unlike silybin or isosilybin, silydianin does not have its diastereomer. Silydianin possesses four hydroxyl groups at $\mathrm{C}_{3}, \mathrm{C}_{5}$, $\mathrm{C}_{7}$, and $\mathrm{C}_{19}$ (3-OH, 5-OH, 7-OH, and 19-OH) (Fig. 1).

Taxifolin is a flavonoid and has molecular weight and chemical formula of $304 \mathrm{~g} / \mathrm{mol}$ and $\mathrm{C}_{15} \mathrm{H}_{12} \mathrm{O}_{7}$, respectively (Fig. 1). Flavonolignans found in silymarin are synthesized from taxifolin and therefore the basic structures of silymarin flavonolignans are taxifolin (Althagafy et al., 2014). There are five hydroxyl groups in taxifolin and they are located at $\mathrm{C}_{3}, \mathrm{C}_{5}, \mathrm{C}_{7}, \mathrm{C}_{12}$, and $\mathrm{C}_{13}(3-\mathrm{OH}$, 5-OH, 7-OH, 12-OH, and 13-OH) (Fig. 1). As mentioned above, the number of phenolic hydroxyl groups are directly associated with free radical scavenging capacity. The position of the hydroxyl group also plays an important role in free radical scavenging capacity. The compound with the ortho position of hydroxyl groups was found to be more active in antioxidant activity followed by para and meta positions of compounds due to the compound's ability to form intramolecular hydrogen bonding (Bendary et al., 2013). In taxifolin, two hydroxyl groups, 12-OH and 13-OH are in the ortho position and this may contribute a large portion of the free radical scavenging capacity of taxifolin.

\section{Total phenolic content of silymarin}

Silymarin is a mixture of polyphenolic compounds. Dietary polyphenols are natural compounds found in fruits, vegetables, herbs, spices, and tea (Shahidi and Ambigaipalan, 2015) and possibly work as antioxidants in the human body. In the human body, reactive oxygen species (ROS) are continuously generated either endogenously (mitochondria, phagocytes, and peroxisomes) or exogenously (cigarette smoking, ultraviolet light, pesticides, and alcohol) (Babusikova et al., 2012). The excessive amount of free radical generated inside the body can cause oxidative stress which is an imbalance between free radicals and antioxidants. Oxidative stress can cause damage to proteins, lipids, DNA, and RNA. As a result, oxidative stress can cause many chronic diseases such as cardiovascular disease, cancer, Alzheimer's disease, and diabetes (Willcox et al., 2010). Therefore, quenching free radicals through dietary intervention (polyphenols) may lower the risk of chronic diseases. However, different foods have varying amounts of phenolics, and thus measuring total phenolic content (TPC) is important for nutraceutical and functional foods development. The total phenolic content in foods is associated with free radical scavenging capacity.

Asghar and Masood evaluated TPC of silymarin purchased from a pharmaceutical company (Asghar and Masood, 2008) (Table 1). The concentration of silymarin was $0.1 \mathrm{mg} / \mathrm{mL}$ and TPC value was $0.484 \pm 0.017 \mathrm{mg}$ gallic acid equivalent $/ \mathrm{mg}$ of dry weight (Asghar and Masood, 2008). Malekinejad and others tested the total phenolic content of five different concentrations of silymarin (Malekinejad et al., 2012) (Table 1). The concentrations were $1,10,25,50$, and $100 \mathrm{mg} / \mathrm{mL}$ of silymarin and TPC values were $560.2 \pm 19.5$, $6,055.2 \pm 214,7,255.3 \pm 308.6,13,016.0 \pm 538.9$, and 23,088.8 \pm $1,730.3 \mathrm{mg}$ gallic acid equivalent (GAE)/mg of silymarin powder, respectively (Malekinejad et al., 2012). The result of this research showed that the total phenolic content of silymarin was concentration dependent. Tupe and others extracted silymarin from milk thistle seed by using methanol as a solvent. The concentration of silymarin extract was $1 \mathrm{~g} / 100 \mathrm{~mL}$ and TPC value was $18.33 \pm 0.16$ mg GAE/g of milk thistle seed (Table 1) (Tupe et al., 2013). Three research groups evaluated the total phenolic content of silymarin in 2016. Pientaweeratch and others used silymarin extract from a pharmaceutical company and found TPC value of $233.37 \pm 7.53$ mg GAE/g of extract (Table 1) (Pientaweeratch et al., 2016). Ismaili and others extracted silymarin from milk thistle seeds using the Soxhlet apparatus and ethanol as a solvent. The concentration of silymarin extract was $0.5 \mathrm{~g} / \mathrm{mL}$ and TPC value was $45.31 \mathrm{mg}$ GAE/g of dry weight milk thistle seed (Table 1) (Ismaili et al., 2016). The last group, Mhamdi and others, extracted silymarin by shaking and using methanol as a solvent. The concentration of silymarin extract was $0.25 \mathrm{mg} / \mathrm{mL}$ and TPC value was $29 \mathrm{mg} \mathrm{GAE} / \mathrm{g}$ dry weight (Table 1) (Mhamdi et al., 2016). In 2017, Attia and others evaluated TPC of milk thistle seeds and found TPC value of $392.1 \pm 5.6 \mathrm{mg} \mathrm{GAE} / 100 \mathrm{~g}$ (Table 1) (Attia et al., 2017).

As shown in Table 1, TPC values of silymarins are widely varying. The most important reason for the variation may differences in chemical composition. As mentioned earlier, German and New Zealand milk thistle had different compositions of silymarin (Martin et al., 2006) and this variation is shown in other studies of silymarin in Table 1. Another reason for the variation in TPC might be differences in extraction methods. Silymarin does not dissolve well in water, but extraction with ethanol or methanol will increase the extraction efficacy and make a notable difference in silymarin's chemical composition and TPC.

For comparison with other plants, the TPC values of silymarins have been shown to be higher than typical TPC values of wheat. Wheat is one of the most consumed cereals in the world and can be used as a good indicator of TPC. In 2005, Moore and others extracted eight different varieties of wheat using $50 \%$ acetone as a solvent and evaluated TPC. The eight different varieties of wheat extract had TPC values in a range of $0.4-0.8 \mathrm{mg} \mathrm{GAE} / \mathrm{g}$ (Moore et al., 2005). In contrast to the wheat extracts, the ethanolic extract of milk thistle seed showed TPC value of $45.31 \mathrm{mg} \mathrm{GAE} / \mathrm{g}$ 
Table 1. Total phenolic content of silymarin

\begin{tabular}{|c|c|c|c|}
\hline Source/Extraction method/Solvent & $\begin{array}{l}\text { Extract con- } \\
\text { centration }\end{array}$ & Total phenolic content & Reference \\
\hline $\begin{array}{l}\text { Silymarin extract from Darou-Pakhs } \\
\text { pharmaceutical company }\end{array}$ & - & $0.484 \pm 0.017 \mathrm{mg} \mathrm{GAE} / \mathrm{mg}$ of silymarin & $\begin{array}{l}\text { Asghar and } \\
\text { Masood, } 2008\end{array}$ \\
\hline Silymarin powder from Sigma Aldrich & $\begin{array}{l}1,10,25,50 \\
\text { and } 100 \mathrm{mg} / \mathrm{mL}\end{array}$ & $\begin{array}{l}560.2 \pm 19.5,6055.2 \pm 214,7255.3 \pm \\
308.6,13,016.0 \pm 538.9, \text { and } 23,088.8 \pm \\
1730.3 \mathrm{mg} \mathrm{GAE} / \mathrm{mg} \text { of silymarin powder }\end{array}$ & $\begin{array}{l}\text { Malekinejad } \\
\text { et al., } 2012\end{array}$ \\
\hline Milk thistle seed/Stirring/Methanol & $1 \mathrm{~g} / 100 \mathrm{~mL}$ & $18.33 \pm 0.16 \mathrm{mg} \mathrm{GAE} / \mathrm{g}$ of milk thistle seed & Tupe et al., 2013 \\
\hline Milk thistle seed/Soxhlet/Ethanol & $\begin{array}{l}0.5 \mathrm{~g} \text { of milk } \\
\text { thistle seeds } / \mathrm{mL}\end{array}$ & $45.31 \mathrm{mg} \mathrm{GAE} / \mathrm{g}$ of dry weight milk thistle seed & Ismaili et al., 2016 \\
\hline Milk thistle seed/Shaking/Methanol & $0.25 \mathrm{mg} / \mathrm{mL}$ & 29 mg GAE/g dry weight & $\begin{array}{l}\text { Mhamdi et } \\
\text { al., } 2016\end{array}$ \\
\hline $\begin{array}{l}\text { Silymarin extract from Berlin pharmaceutical } \\
\text { industry/Maceration/Ethanol }\end{array}$ & - & $233.37 \pm 7.53 \mathrm{mg} \mathrm{GAE} / \mathrm{g}$ of extract & $\begin{array}{l}\text { Pientaweeratch } \\
\text { et al., } 2016\end{array}$ \\
\hline Milk thistle seed & - & $392.1 \pm 5.6 \mathrm{mg} \mathrm{GAE} / 100 \mathrm{~g}$ & Attia et al., 2017 \\
\hline
\end{tabular}

Abbreviation: GAE, Gallic acid equivalents.

and methanolic extract of milk thistle seed showed TPC value of 29 mg GAE/g (Ismaili et al., 2016; Mhamdi et al., 2016). Even though the extraction methods were different, ethanolic extract of milk thistle seed had about 57-113 times greater TPC than wheat extract. Methanolic extract of milk thistle seed had about 36-73 times greater TPC values compared to TPC values of eight varieties of wheat extracted with 50\% acetone. The high phenolic content seems to be associated with numerous health beneficial effects such as free radical scavenging and anti-proliferative capacity.

\section{Free radical scavenging capacities of silymarin}

Excessive free radicals generated inside the human body can cause oxidative stress. Oxidative stress is closely associated with inflammation and chronic diseases. Therefore, quenching free radicals may reduce the risk of getting chronic diseases. Dietary polyphenols can neutralize free radicals and therefore may be a dietary intervention important for human health. However, each plant contains different amounts of polyphenolic compounds and has different free radical scavenging capacity. Even though TPC is an indicator of free radical scavenging capacity, the relationship is not directly proportional. Also, free radical scavenging capacity can vary depending on the structure of polyphenolic compounds and free radical species. Therefore, evaluating free radical scavenging capacities is also important for the development of nutraceuticals and functional foods.

There are several free radical scavenging capacity assays available that measure different types of free radicals. Peroxyl and hydroxyl radicals are physiologically relevant free radicals and oxygen radical absorbing capacity (ORAC) and hydroxyl radical scavenging capacity (HOSC) assays are used for the measurement of these free radicals. Peroxyl radical is an important physiological radical since it can be possibly involved in the propagating steps of the lipid peroxidation chain reaction. The hydroxyl radical $\left({ }^{\circ} \mathrm{OH}\right)$ is extremely reactive with almost every type of biomolecules and is possibly the most reactive chemical species among physiologically relevant reactive oxygen species (Halliwell \& Cross, 1994).

2,2-diphenyl-1-picrylhydrazyl (DPPH) and (2,2'-azino-bis(3- ethylbenzothiazoline-6-sulfonic acid) (ABTS) radical scavenging capacity assays are chemical-based and color changes are measured. The DPPH radicals have violet color which has a strong absorption at $517 \mathrm{~nm}$. When the antioxidant donates its electron to DPPH free radicals, the violet color turns to yellow and this decolorization is used to measure the DPPH free radical scavenging capacity. The ABTS cation radicals have a dark green color and absorption of $734 \mathrm{~nm}$. Similar to the DPPH assay, ABTS radical scavenging capacity assay is also a decolorization assay. Once ABTS cation radical reacts with antioxidants, the dark green color turns transparent. The benefit of these two chemical-based assays is that they are easy to perform.

Asghar and Masood evaluated silymarin's DPPH free radical scavenging capacity and found half-maximal effective concentration $\left(\mathrm{EC}_{50}\right)$ of $1.34 \mathrm{mg} / \mathrm{mL}$ (Asghar and Masood, 2008) (Table 2). Köksal and others evaluated three free radical scavenging capacities of silymarin including HOSC, DPPH, and ABTS (Köksal et al., 2009). They extracted silymarin by boiling water and the concentration of silymarin extract was $30 \mu \mathrm{g}$ of silymarin $/ \mathrm{mL}$. They found that DPPH and ABTS had $\mathrm{EC}_{50}$ of $20.8 \mu \mathrm{g} / \mathrm{mL}$ and $8.62 \mu \mathrm{g} /$ $\mathrm{mL}$, respectively (Table 2 ). Also, silymarin extract showed $78.5 \%$ inhibition of hydroxyl radical (Köksal et al., 2009) (Table 2). Both Asghar and Masood and Köksal's group evaluated DPPH free radical scavenging capacity but the results were quite different. Asghar and Masood had $\mathrm{EC}_{50}$ of $1.34 \mathrm{mg} / \mathrm{mL}$ while Köksal and others had $\mathrm{EC}_{50}$ of $20.8 \mu \mathrm{g} / \mathrm{mL}$. There are two possible reasons for the difference in results. The concentration used to test DPPH free radical scavenging capacity was $30 \mu \mathrm{g}$ of silymarin/mL for Köksal and others but Asghar and Masood did not mention the concentration of the silymarin they used. The concentration of silymarin that Asghar and Masood used may be much higher than the silymarin concentration used by Köksal and others (Köksal et al., 2009). Another possible reason for the difference is the extraction method. Asghar and Masood purchased silymarin extract from a pharmaceutical company and therefore the extraction solvent is unknown. Often silymarin is extracted using ethanol, methanol, dimethyl sulfoxide (DMSO), acetone, and dimethylformamide (DMF). Köksal and others (Köksal et al., 2009) used water to extract silymarin and unlike organic solvents, silymarin is not highly soluble in water. These are two possible reasons for differences in DPPH radical scavenging capacity, but other factors such as difference in cultivar 
Table 2. Free radical scavenging capacities of silymarin

\begin{tabular}{|c|c|c|c|c|}
\hline Source/Extraction method/Solvent & $\begin{array}{l}\text { Extract con- } \\
\text { centration }\end{array}$ & $\begin{array}{l}\text { Experimental } \\
\text { methods }\end{array}$ & $\begin{array}{l}\text { Free radical scaveng- } \\
\text { ing capacities }\end{array}$ & Reference \\
\hline $\begin{array}{l}\text { Silymarin extract purchased from Darou- } \\
\text { Pakhs pharmaceutical company }\end{array}$ & - & DPPH & $1.34 \mathrm{mg} / \mathrm{mL}\left(\mathrm{EC}_{50}\right)$ & $\begin{array}{l}\text { Asghar and } \\
\text { Masood, } 2008\end{array}$ \\
\hline \multirow[t]{3}{*}{ Milk thistle seed powder/Boiling/Water } & \multirow{3}{*}{$\begin{array}{l}30 \mu \mathrm{g} \text { of } \\
\text { silymarin/mL }\end{array}$} & HOSC & $78.5 \%$ & \multirow[t]{3}{*}{ Köksal et al., 2009} \\
\hline & & DPPH & $20.8 \mu \mathrm{g} / \mathrm{mL}\left(\mathrm{EC}_{50}\right)$ & \\
\hline & & ABTS & $8.62 \mu \mathrm{g} / \mathrm{mL}\left(\mathrm{EC}_{50}\right)$ & \\
\hline Silymarin powder from Sigma Aldrich & $\begin{array}{l}1,10,25,50 \\
\text { and } 100 \mathrm{mg} / \mathrm{mL}\end{array}$ & DPPH & $\begin{array}{l}6.0 \pm 0.7,14.1 \pm 1.8,25.7 \pm 3.3 \\
39.7 \pm 2.4, \text { and } 54.2 \pm 5.6 \%\end{array}$ & $\begin{array}{l}\text { Malekinejad } \\
\text { et al., } 2012\end{array}$ \\
\hline \multirow[t]{2}{*}{ Milk thistle seed/Stirring/Methanol } & \multirow[t]{2}{*}{$1 \mathrm{mg} / \mathrm{mL}$} & DPPH & $92.45 \pm 1.91 \%$ & \multirow[t]{2}{*}{ Tupe et al., 2013} \\
\hline & & ABTS & $53.44 \pm 0.71 \%$ & \\
\hline \multirow[t]{2}{*}{ Milk thistle/Soxhlet/Ethanol } & \multirow[t]{2}{*}{$\begin{array}{l}0.5 \mathrm{~g} \text { of milk } \\
\text { thistle seeds } / \mathrm{mL}\end{array}$} & DPPH & $\begin{array}{l}353.89 \pm 3.68 \mathrm{mg} \\
\text { TE/g dry weight }\end{array}$ & \multirow[t]{2}{*}{ Ismaili et al., 2016} \\
\hline & & ABTS & $\begin{array}{l}805.25 \pm 16.90 \mathrm{mg} \\
\mathrm{TE} / \mathrm{g} \text { dry weight }\end{array}$ & \\
\hline \multirow{2}{*}{$\begin{array}{l}\text { Silymarin extract from Berlin pharmaceutical } \\
\text { industry/Maceration/Ethanol }\end{array}$} & \multirow[t]{2}{*}{-} & DPPH & $27.85 \pm 0.98 \mu \mathrm{g} / \mathrm{mL}\left(\mathrm{EC}_{50}\right)$ & \multirow{2}{*}{$\begin{array}{l}\text { Pientaweeratch } \\
\text { et al., } 2016\end{array}$} \\
\hline & & ABTS & $12.34 \pm 0.21 \mu \mathrm{g} / \mathrm{mL}\left(\mathrm{EC}_{50}\right)$ & \\
\hline Milk thistle seed/Shaking/Methanol & $0.25 \mathrm{mg} / \mathrm{mL}$ & DPPH & $39 \mu \mathrm{g} / \mathrm{mL}\left(\mathrm{IC}_{50}\right)$ & $\begin{array}{l}\text { Mhamdi et } \\
\text { al., } 2016\end{array}$ \\
\hline \multirow{4}{*}{$\begin{array}{l}\text { Milk thistle seed flour/ } \\
\text { Sonication/50\% acetone }\end{array}$} & $200 \mathrm{mg} \mathrm{FE} / \mathrm{mL}$ & DPPH & $48.61 \pm 6.47 \mu \mathrm{mol} \mathrm{TE} / \mathrm{g}$ & \multirow[t]{4}{*}{ Choe et al., 2019} \\
\hline & $43 \mathrm{mg} \mathrm{FE} / \mathrm{mL}$ & ORAC & $633.57 \pm 267.17 \mu \mathrm{mol} \mathrm{TE} / \mathrm{g}$ & \\
\hline & $40 \mathrm{mg} \mathrm{FE} / \mathrm{mL}$ & HOSC & $10,420.28 \pm 607.58 \mu \mathrm{mol} T E / g$ & \\
\hline & $30 \mathrm{mg} \mathrm{FE} / \mathrm{mL}$ & ABTS & $116.16 \pm 16.81 \mu \mathrm{mol} T E / g$ & \\
\hline
\end{tabular}

Abbreviations: DPPH, 2,2-diphenyl-1-picrylhydrazyl radical scavenging capacity assay; ABTS, 2,2'-azino-bis(3-ethylbenzothiazoline-6-sulfonic acid) radical scavenging capacity assay; ORAC, Oxygen radical absorbing capacity assay; HOSC, Hydroxyl radical scavenging capacity assay; TE, Trolox equivalents; FE, Flour equivalents.

may cause the variation.

Malekinejad and others evaluated DPPH free radical scavenging capacity of five different concentrations $(1,10,25,50$, and 100 $\mathrm{mg} / \mathrm{mL}$ ) of silymarin and found \% inhibition of $6.0 \pm 0.7,14.1 \pm$ $1.8,25.7 \pm 3.3,39.7 \pm 2.4$, and 54.2 \pm 5.6 , respectively (Malekinejad et al., 2012) (Table 2). Similarly, Tupe and others extracted silymarin from milk thistle seed using a stirring method with methanol as a solvent and evaluated DPPH and ABTS free radical scavenging capacities. The concentration of silymarin extract was $10 \mathrm{mg} / \mathrm{mL}$ and $\%$ inhibition was $92.45 \pm 1.91$ and $53.44 \pm 0.71 \%$, respectively (Tupe et al., 2013) (Table 2). Interestingly, both Malekinejad and Tupe's groups used methanol as a solvent and had a common concentration of $10 \mathrm{mg} / \mathrm{mL}$. However, their results were significantly different. For Malekinejad and others, the percent inhibition reported for DPPH radical at $10 \mathrm{mg} / \mathrm{mL}$ of silymarin was $14.1 \pm 1.8$ (Malekinejad et al., 2012). The percent inhibition reported by Tupe and others using the same concentration was 92.45 \pm 1.91 (Tupe et al., 2013).

In 2016, Ismaili and others extracted silymarin using the Soxhlet apparatus with ethanol as a solvent and evaluated DPPH and ABTS free radical scavenging capacities (Ismaili et al., 2016). The concentration of silymarin extract was $0.5 \mathrm{~g} / \mathrm{mL}$ and DPPH and ABTS values were $353.89 \pm 3.68$ and $805.25 \pm 16.90 \mathrm{mg}$ Trolox equivalent (TE)/g dry weight, respectively (Ismaili et al., 2016) (Table 2). Recently, our group extracted silymarin using 50\% acetone and evaluated four free radical scavenging capacities including DPPH, ORAC, HOSC, and ABTS. The values of DPPH, ORAC, HOSC and ABTS were 48.61 $\pm 6.47,633.57 \pm 267.17$,
$10,420.28 \pm 607.58$, and $116.16 \pm 16.81 \mathrm{TE} / \mathrm{g}$ and concentrations were $200,43,40$, and $30 \mathrm{mg}$ flour equivalents $/ \mathrm{mL}$, respectively (Choe et al., 2019) (Table 2). Interestingly, Ismaili's and our group had a similar trend in DPPH and ABTS free radical scavenging capacity in that both extracts showed greater free radical scavenging capacity against ABTS radical compared to DPPH radical. However, DPPH and ABTS values were different and this is probably due to the difference in solvents. Our group used 50\% acetone as a solvent and Ismail and others used ethanol.

Pientaweeratch and others also evaluated DPPH and ABTS free radical scavenging capacities of silymarin (Pientaweeratch et al., 2016). Silymarin extract was purchased from a pharmaceutical company and $\mathrm{EC}_{50}$ for DPPH and ABTS were $27.85 \pm 0.98$ and $12.34 \pm 0.21 \mu \mathrm{g} / \mathrm{mL}$, respectively (Pientaweeratch et al., 2016) (Table 2). Interestingly, these values were comparable to that of Köksal and others' DPPH and ABTS values of $20.8 \mu \mathrm{g} / \mathrm{mL}$ and $8.62 \mu \mathrm{g} / \mathrm{mL}$, respectively (Köksal et al., 2009). In the same year, Mhamdi and others evaluated silymarin's DPPH free radical scavenging capacity. They extracted silymarin from milk thistle seeds using the shaking method with methanol as a solvent. The concentration of silymarin extract was $0.25 \mathrm{mg} / \mathrm{mL}$ and the halfmaximum inhibitory concentration $\left(\mathrm{IC}_{50}\right)$ for DPPH was $39 \mu \mathrm{g} / \mathrm{mL}$ (Mhamdi et al., 2016) (Table 2).

The results from these studies suggest that silymarin possesses strong free radical scavenging capacities against different types of free radicals. Differences in reporting methods and extraction solvents can make the comparison of results difficult among studies. However, because of the antioxidant activity demonstrated, sily- 
Table 3. Anti-cancer activities of silymarin in different types of cancers

\begin{tabular}{|c|c|c|c|}
\hline Cancer & Experiment subject & Compound used & Reference \\
\hline \multirow[t]{3}{*}{ Bladder } & $\begin{array}{l}N \text {-buthyl- } N \text {-(4-hydroxybuthyl) nitrosamine }(\mathrm{OH}- \\
\text { BBN) induced bladder cancer in mice }\end{array}$ & Silibinin & Tyagi et al., 2007 \\
\hline & T24, and UM-UC-3 bladder cancer cell lines & Silibinin & Imai-sumida et al., 2017 \\
\hline & $\begin{array}{l}\text { T24 and J82 bladder cancer cell lines and their } \\
\text { chemoresistant bladder cancer cell lines, } T 24^{R} \text { and } J 82^{R}\end{array}$ & Silibinin & Sun et al., 2017 \\
\hline \multirow[t]{3}{*}{ Breast } & MDA-MB 468 breast cancer cell line & Silymarin & Zi et al., 1998 \\
\hline & MCF-7 breast cancer cell line & Silibinin & Noh et al., 2011 \\
\hline & MCF-7 breast cancer cell line & Silymarin & Kalla et al., 2014 \\
\hline \multirow[t]{4}{*}{ Colon } & Azoxymethane (AOM) induced colon cancer in rat & Silymarin & Kohno et al., 2002 \\
\hline & Fet, Geo, and HCT-116 colon cancer cell lines & Silibinin & Hogan et al., 2006 \\
\hline & HT-29 colon cancer cell line & Silibinin & Akhtar et al., 2014 \\
\hline & HCT-116 and SW480 colon cancer cell lines & Silymarin & Eo et al., 2015 \\
\hline \multirow[t]{2}{*}{ Gastric } & $\begin{array}{l}\text { Matrix metallopeptidase } 9 \text { (MMP-9) expression } \\
\text { levels in SNU216 and SNU688 gastric cancer cell lines } \\
\text { induced with tumor necrosis factor alpha (TNF- } \alpha \text { ) }\end{array}$ & Silibinin & Kim et al., 2009 \\
\hline & MGC803 gastric cancer cell line & Silibinin & Wang et al., 2014 \\
\hline \multirow[t]{2}{*}{ Kidney } & Caki-1 renal carcinoma cell line & Silibinin & Li et al., 2008 \\
\hline & ACHN, OS-RC-2, and SW839 renal carcinoma cell lines & Silibinin & Liang et al., 2012 \\
\hline \multirow[t]{3}{*}{ Lung } & SHP-77 and A-549 lung cancer cell lines & Silibinin & Sharma et al., 2003 \\
\hline & H1299, H460, and H322 lung cancer cell lines & Silibinin & Mateen et al., 2010 \\
\hline & A549, H1299, and H460 lung cancer cell lines & Silymarin & Singh et al., 2016 \\
\hline Oral & $\begin{array}{l}\text { HSC-4, YD15, and Ca9-22 oral cancer cell lines } \\
\text { and HSC-4 injected xenograft model in rats }\end{array}$ & Silymarin & Won et al., 2018 \\
\hline \multirow[t]{2}{*}{ Ovarian } & A2780 ovarian cancer cell line & Silibinin & Scambia et al., 1996 \\
\hline & A2780 and PA-1 ovarian cancer cell lines & Silymarin & Fan et al., 2014 \\
\hline \multirow[t]{13}{*}{ Prostate } & DU145 prostate cancer cell line & Silymarin & Zi et al., 1998 \\
\hline & LNCaP prostate cancer cell line & Silibinin & Zi and Agarwal, 1999 \\
\hline & PC-3 prostate cancer cell line & Silibinin & Zi et al., 2000 \\
\hline & LNCaP prostate cancer cell line & Silibinin & Zhu, 2001 \\
\hline & DU145 prostate cancer cell line & Silymarin & Bhatia and Agarwal, 2001 \\
\hline & LNCaP and DU145 prostate cancer cell lines & Silymarin & Sharma et al., 2001 \\
\hline & DU145 prostate cancer cell line & Silibinin & Dhanalakshmi et al., 2002 \\
\hline & DU145 prostate cancer cell line & Silibinin and Doxorubicin & Tyagi et al., 2002 \\
\hline & DU145 xenograft model in mice & Silibinin & Singh et al., 2002 \\
\hline & DU145 prostate cancer cell line & Silibinin and cisplatin & Dhanalakshmi et al., 2003 \\
\hline & LNCaP, DU145, and PC-3 prostate cancer cell lines & $\begin{array}{l}\text { Each flavonolignan } \\
\text { found in silymarin }\end{array}$ & Davis-Searles et al., 2005 \\
\hline & LNCaP and 22Rv1 prostate cancer cell lines & Isosilybin A and isosilybin B & Deep et al., 2007 \\
\hline & ARCaP prostate cancer cell line & Silibinin & Wu et al., 2010 \\
\hline \multirow[t]{4}{*}{ Skin } & $\begin{array}{l}\text { UVB and 7, 12-dimethylbenz[a]anthracene- } \\
\text { induced tumor in mouse skin model }\end{array}$ & Silymarin & Kativar et al., 1997 \\
\hline & A431 human epidermoid carcinoma cell line & Silymarin & Ahmad et al., 1998 \\
\hline & SKH-1 hairless mice & Silibinin & Dhanalakshmi et al., 2004 \\
\hline & JB6 mouse epithelial cell model & Silibinin & Singh et al., 2006 \\
\hline
\end{tabular}


marin may be useful in nutraceuticals or functional foods to help prevent chronic diseases.

\section{Anti-cancer activities of silymarin}

Cancer is the second leading cause of death worldwide and involves severe tumor progression and metastasis. Investigating natural compounds that possess anti-cancer activity is important for developing drugs or nutraceuticals for cancer treatment. Silymarin is a natural extract from milk thistle seed which possesses anti-cancer activity against a number of cancers including bladder (Tyagi et al., 2007; Imai-sumida et al., 2017; Sun et al., 2017), breast (Zi et al., 1998; Noh et al., 2011; Kalla et al., 2014), colon (Kohno et al., 2002; Hogan et al., 2006; Akhtar et al., 2014; Eo et al., 2015), gastric (Kim et al., 2009; Wang et al., 2014), kidney (Li et al., 2008; Liang et al., 2012), lung (Sharma et al., 2003; Mateen et al., 2010; Singh et al., 2016), oral (Won et al., 2018), ovarian (Scambia et al., 1996; Fan et al., 2014), prostate (Zi et al., 1998; Zi and Agarwal, 1999; Zhu, 2001; Bhatia and Agarwal, 2001; Sharma et al., 2001; Dhanalakshmi et al., 2002; Tyagi et al., 2002; Singh et al., 2002; Dhanalakshmi et al., 2003; Davis-Searles et al., 2005; Deep et al., 2007; Wu et al., 2010), and skin (Kativar et al., 1997; Ahmad et al., 1998; Dhanalakshmi et al., 2004; Singh et al., 2006) with minimal side effects (Table 3 ). In this section, the anti-cancer activity of silymarin and its components will be discussed.

\subsection{Bladder cancer}

Bladder cancer is the fourth most common cancer in men and the eighth-most common cancer in women (Metts et al., 2000). Previously, epidemiologic studies found that urothelial tumors are associated with risk factors such as cigarette smoking and chemical carcinogen exposure (Freedman et al., 2011). In 2007, Tyagi and others evaluated the anti-cancer activity of silymarin and its component, silibinin in bladder cancer. They induced bladder cancer by tobacco smoke carcinogen $N$-buthyl- $N$-(4-hydroxybuthyl) nitrosamine $(\mathrm{OH}-\mathrm{BBN})$ and fed mice silymarin or silibinin for 6 weeks. As a result, they found silymarin and silibinin decreased bladder cancer cell proliferation by 42 and $44 \%$, and apoptosis was increased by 4-fold and 6-fold, respectively (Tyagi et al., 2007). They revealed that these anti-proliferative and apoptotic effects of silymarin and silibinin were associated with cell cycle arrest. Cyclin D1 and extracellular signal-regulated kinase 1/2 phosphorylation $(p E R K 1 / 2)$ are proteins required for cell cycle progression. They found significantly decreased protein levels of cyclin D1 and $p$ ERK1/2 in silymarin and silibinin fed mice. In 2017, Imai-sumida, and others also reported anti-cancer activity of silymarin's component, silibinin in bladder cancer cell lines. They found that $10 \mu \mathrm{M}$ silibinin significantly induced apoptosis and suppressed cell proliferation, migration, and invasion of T24 and UM-UC-3 human bladder cancer cells (Imai-sumida et al., 2017). These anti-cancer activities were due to the down-regulation of the actin cytoskeleton and phosphatidylinositide 3-kinase (PI3K)/ Akt in these cancer cell lines. Moreover, Sun and others tested the anti-cancer activity of bladder cancer cells and chemoresistance (Sun et al., 2017). They found attenuated migration, invasion, and proliferation of human bladder cancer cell lines T24 and J82 in the presence of silibinin. Also, silibinin showed anti-cancer activity in chemoresistant bladder cancer cell lines $\mathrm{T} 24^{\mathrm{R}}$ and $\mathrm{J} 82^{\mathrm{R}}$, which originated from T24 and J82 induced by cisplatin. The mechanism of action in suppressing malignancy of bladder cancer cells was through NF-kB-dependent and -independent signaling pathways (Sun et al., 2017).

\subsection{Breast cancer}

Breast cancer is the most common cancer in women. Silymarin has been shown to have anti-cancer activity in breast cancer cells. In $1998, \mathrm{Zi}$ and others evaluated the anti-cancer activity of silymarin in breast cancer cells MDA-MB 468 ( $\mathrm{Zi}$ et al., 1998). They found that the inhibitory effects of silymarin on MDA-MB 468 cells were associated with a G1 cell cycle arrest. In 2011, Noh and others evaluated the anti-cancer activity of silibinin in MCF-7 human breast cancer cells. They found that silibinin showed dose- and time-dependent reduction in MCF-7 human breast cancer cells. Silibinin induced apoptotic cell death in MCF-7 human breast cancer cells through increased p53 expression. The p53 is a protein involved in suppressing cancer cells. In addition, they found that MCF-7 human breast cancer cells treated with silibinin and ultraviolet $\mathrm{B}$ had synergistic effects in suppressing cell viability compared to ultraviolet B treatment or silibinin treatment (Noh et al., 2011). In 2014, Kalla and others also tested the anti-cancer activity of silymarin on MCF-7 human breast cancer cells. Silymarin treatment for 5 days using $200 \mu \mathrm{g}$ showed $48 \%$ inhibition of MCF-7 human breast cancer cells compared to the control. Kalla and others also demonstrated that the anti-proliferative capacity of MCF-7 human breast cancer cells was through p53 protein (Kalla et al., 2014). These studies demonstrate the potential of silymarin to act against breast cancer cells in vitro. Further studies are needed to test in vivo effects of silymarin in prevention of breast cancer.

\subsection{Colon cancer}

Colon cancer is the third common malignancy worldwide (Ferlay et al., 2013). In the United States, colon cancer is the second leading cause of death among cancers. Kohno and others tested silymarin's anti-cancer activity using a rat model. They induced colon carcinogenesis using azoxymethane (AOM) and fed rats with a silymarin supplemented diet. They found that silymarin significantly suppressed the development of AOM induced colonic carcinoma (Kohno et al., 2002). Hogan and others tested cell cycle arrest of colon cancer using silibinin (Hogan et al., 2006). They found that silibinin was able to inhibit the proliferation of colon cancer cell lines, Fet, Geo, and HCT-116 through cell cycle arrest. Akhtar and others evaluated the anti-proliferative action of silibinin on colon cancer cell line HT-29. They found that silibinin showed inhibition of cell growth in a time-dependent manner. $\mathrm{IC}_{50}$ values were 180,100 , and $40 \mu \mathrm{g} / \mathrm{mL}$ at 24, 48, and $72 \mathrm{~h}$, respectively (Akhtar et al., 2014). Eo and others evaluated anti-cancer activities of silymarin in two colon cancer cell lines, HCT-116 and SW480 (Eo et al., 2015). They used three different concentrations of silymarin including 50,100, and $200 \mu \mathrm{M}$, and found that anti-proliferation of both cell lines was dose dependent. They revealed that antiproliferative action was due to the cell cycle arrest and associated with cyclin D1. The cyclin D1 protein levels were also dose- and timedependence. These studies demonstrate the potential of silymarin to inhibit growth of colon cancer cells.

\subsection{Gastric cancer}

Gastric cancer is often associated with diet and lifestyle factors. Risk factors for gastric cancer include a diet high in salt and 
smoked foods, a diet low in fruits and vegetables, family history, and smoking. Kim and others evaluated matrix metallopeptidase 9 (MMP-9) expression levels in gastric cancer cell lines, SNU216 and SNU668, induced with tumor necrosis factor-alpha (TNF- $\alpha$ ). In general, MMP-9 is increased in the pathogenesis of gastric cancer. This study found that silibinin was able to suppress MMP-9 mRNA expression and protein levels in a dose-dependent manner (Kim et al., 2009). Wang and others evaluated the anti-cancer activity of silibinin using the MGC803 gastric cancer cell line. They found that silibinin suppressed the growth of MGC803 gastric cancer cells in a dose- and time-dependent manner. Also, silibinin induced apoptosis and cell cycle arrest in MGC 803 gastric cancer cells (Wang et al., 2014). These studies show promising effects of silibinin against gastric cancer at the cellular level.

\subsection{Kidney cancer}

Renal cell carcinoma (RCC) is the most prevalent and lethal carcinoma of the kidney in adults (Li et al., 2008). About 20 to $30 \%$ of patients have metastasis at the time of diagnosis and thus the prognosis is extremely poor. $\mathrm{Li}$ and others evaluated the anti-cancer activity of silibinin and found the inhibitory proliferation effects of silibinin in Caki-1 renal carcinoma cell growth (Li et al., 2008). The apoptosis was through inhibiting the activation of epidermal growth factor receptor (EGFR) and extracellular signal-regulated kinases $1 / 2$ (ERK1/2). Liang and others tested the anti-cancer activity of silibinin in RCC including ACHN, OS-RC-2, and SW839 cell lines and found suppressed RCC cell progression. Interestingly, the mechanism of actions in ACHN, OS-RC-2, and SW839 cell lines was through inhibiting the activation of EGFR, the same mechanism of action previously reported in cell line Caki-1 (Liang et al., 2012).

\subsection{Lung cancer}

According to the American Cancer Society, lung cancer accounts for $25 \%$ of all cancer deaths. More than half of people diagnosed with lung cancer die within one year of diagnosis and the 5-year survival rate is less than $18 \%$ (Zappa and Mousa, 2016). Sharma and others tested anti-cancer activities of silibinin in two lung cancer cell lines, SHP-77 and A-549 (Sharma et al., 2003). They used three different concentrations of silibinin $(25,50$, and $100 \mu \mathrm{M})$ and found cell growth inhibition and apoptosis in a dose- and timedependent manner. Mateen and others evaluated silibinin's anticancer activity using H1299, H460, and H322 lung cancer cells (Mateen et al., 2010). They treated lung cancer cells with silibinin concentrations of $10,25,50$, and $75 \mu \mathrm{M}$ and found a dose- and time-dependent anti-proliferation. Singh and others evaluated the effects of silymarin on lung cancer cell migration (Singh et al., 2016). They used three lung cancer cell lines, A549, H1299, and $\mathrm{H} 460$ with silymarin concentrations of $0,5,10$, and $20 \mu \mathrm{g} / \mathrm{mL}$ and found concentration-dependent inhibition of cell migration. These studies show the potential of silibinin to exert anti-proliferative activity on lung cancer cells. Futher studies on the effects of dietary silibinin on lung cancer prevention would be beneficial.

\subsection{Oral cancer}

Oral cancer has a poor prognosis and the 5-year survival rate is lower than $50 \%$. This is due to local recurrence and metastasis. Therefore, over the last decade, finding effective drug candidates has been focused to increase the survival rate of patients. In 2018, Won and others tested silymarin's anti-cancer activity in human oral cancer in vitro and in vivo (Won et al., 2018). They tested anti-proliferative capacities of silymarin in human oral cancer cell lines, HSC-4, YD15, and Ca9-22. As a result, silymarin suppressed the proliferation of all three oral cancer cells. In addition, they found that silymarin inhibited oral tumor growth and volume in HSC-4 oral cancer cell injected xenograft model rats without any hepatic or renal toxicity. This study shows the potential of silymarin in prevention of oral cancer growth.

\subsection{Ovarian cancer}

Ovarian cancer is the most lethal in gynecologic cancers. Often ovarian cancer is asymptomatic and diagnosed at an advanced stage (Fan et al., 2014). Drugs used to treat ovarian cancer have strong adverse effects such as skin and gastrointestinal toxicity (Glaysher et al., 2013). Therefore, herbal medicine with little side effects such as silymarin may useful in ovarian cancer treatment. In 1996, Scambia and others tested the anti-proliferative activity of silibinin on the human ovarian cancer cell line, A2780 (Scambia et al., 1996). They found that silibinin was effective in inhibiting A2780 ovarian cancer cells. In 2014, Fan and others tested silymarin's anti-cancer activities in ovarian cancer cell lines, A2780 and PA-1 (Fan et al., 2014). They found that silymarin significantly suppressed cell growth in a dose- and time-dependent manner, and arrested cell cycle progression.

\subsection{Prostate cancer}

Prostate cancer is the most prevalent cancer in men. Risk factors for prostate cancer include family history, smoking, physical activity, and diet (Watters et al., 2009). There have been several studies that evaluated silymarin's anti-cancer activity against prostate cancer.

$\mathrm{Zi}$ and others evaluated the anti-cancer activity of silymarin using DU145 prostate cancer cell line (Zi et al., 1998). They found that silymarin inhibited growth of human prostate carcinoma DU145 cells and that silymarin induced $\mathrm{G}_{1}$ arrest in DU145 cells. $\mathrm{Zi}$ and Agarwal evaluated silibinin's anti-cancer activity on LN$\mathrm{CaP}$ prostate cancer cells (Zi and Agarwal, 1999). They found that silibinin, the major component of silymarin, was able to inhibit the growth of LNCaP prostate cancer cells through $\mathrm{G}_{1}$ arrest in the cell cycle. Similarly, Zi and others tested silibinin's anti-cancer activity on PC-3 prostate cancer cells (Zi et al., 2000). Like DU145 and LN$\mathrm{CaP}$ prostate cancer cell lines, $\mathrm{PC}-3$ prostate cancer cell line also showed significant growth inhibition with silibinin treatment. Zhu and others evaluated how silymarin and its component, silibinin, regulate androgen receptors in $\mathrm{LNCaP}$ prostate cancer cells (Zhu, 2001). They found that silibinin was able to reduce the nuclear androgen receptor levels. Bhatia and Agarwal evaluated how silymarin prevents the proliferation of human prostate cancer DU145 cells (Bhatia and Agarwal, 2001). The results showed that silymarin suppressed DU145 cell growth through inhibiting ERK1/2 activation. Sharma and others evaluated silymarin's anti-proliferative activity in two prostate cancer cell lines, LNCaP and DU145 (Sharma et al., 2001). This study showed that silibinin showed 20 $40 \%$ and $30-55 \%$ growth inhibitions in LNCaP and DU145 cells, respectively. Dhanalakshmi and others evaluated how silibinin affect DU145 cell's signaling pathways (Dhanalakshmi et al., 2002). They found that activation of NF- $\kappa \mathrm{B}$ through TNF- $\alpha$ was inhibited in DU145 cells by silibinin. Tyagi and others tested silibinin's syn- 
ergistic anti-cancer activity with Doxorubicin in the DU145 prostate cancer cell line (Tyagi et al., 2002). They found that silibinin showed synergistic effects in growth inhibition, cell cycle arrest, and apoptosis in DU145 prostate cancer cells. Singh and others evaluated silibinin's anti-cancer effects in vivo (Singh et al., 2002). Previously, they reported the anti-cancer activity of silibinin in the DU145 prostate cancer cell line. Later they studied the DU145 tumor xenograft model using athymic male nude mice. They found that feeding silibinin diet $(0.05$ and $0.1 \% \mathrm{w} / \mathrm{w})$ for 60 days reduced the tumor volume by 35 and $58 \%$, respectively. They revealed that this result was associated with reduced cell proliferation, increased apoptosis, and inhibition of angiogenesis (Singh et al., 2002). Dhanalakshmi and others tested the synergistic anti-cancer activity of silibinin and cisplatin (Dhanalakshmi et al., 2003), and showed that cisplatin alone at $2 \mu \mathrm{g} / \mathrm{mL}$ dose inhibited $48 \%$ cell growth in DU145 prostate cancer cells. Interestingly, a combination of cisplatin and silibinin $(50-100 \mu \mathrm{M})$ showed $63-80 \%$ growth inhibition. In 2005, Davis-Searles and others evaluated the anti-cancer activity of each flavonolignan found in silymarin (Davis-Searles et al., 2005). They found that isosilybin B was the most potent suppressor of cell growth. Isosilybin A and isosilybin B showed the most effective in suppressing prostate-specific antigen (PSA) secretion by LNCaP cells. Deep and others evaluated isosilybin $\mathrm{A}$ and B's anti-cancer activity in human prostate cancer LNCaP and 22Rv1 cells (Deep et al., 2007). They found that isosilibinin treatment resulted in growth inhibition and cell death together with a strong G1 arrest and apoptosis in both the cell lines. In 2010, $\mathrm{Wu}$ and others tested silibinin's effect in epithelial to mesenchymal transition (EMT). That study demonstrated that silibinin was able to reverse the EMT through inhibiting the NF- $\mathrm{kB}$ signaling pathway in the ARCaP prostate cancer cell line (Wu et al., 2010). From these previous studies, silymarin components appear to have different mechanisms for antiproliferative activity against prostate cancer cells. Silymarin may be effective against prostate cancer in combination with traditional chemotherapy. Further research to study in vivo effects of silymarin against prostate cancer would be beneficial.

\subsection{Skin cancer}

Skin is always vulnerable to damage since it is exposed to pathogens, ultraviolet radiation, and harmful chemicals. These harmful factors can trigger stress and cause skin carcinogenesis (Prasad et al., 2020).

Katiyar and others evaluated the protective effects of silymarin against photocarcinogenesis in a mouse skin model (Katiyar et al., 1997). They used three different stages, 1) UVB-induced tumor initiation followed by phorbol ester-mediated tumor promotion, 2) 7, 12-dimethylbenz[a]anthracene-induced tumor initiation followed by UVB-mediated tumor promotion, and 3) UVB-induced complete carcinogenesis. Silymarin was applied topically at a concentration of $9 \mathrm{mg}$ per application before UVB exposure. As a result, at UVB-induced tumor initiation, silymarin treatment reduced tumor incidence from 40 to $20 \%$. During the UVB-induced tumor promotion stage, silymarin treatment reduced tumor incidence from 100 to $60 \%$. For UVB-induced complete carcinogenesis, silymarin treatment reduced the tumor incidence from 100 to $25 \%$. It is believed that the protective effects of silymarin against photocarcinogenesis are through its strong antioxidant properties. Ahmad and others evaluated the chemopreventive effects of silymarin in A431 human epidermoid carcinoma cell line (Ahmad et al., 1998). They found that silymarin was able to inhibit the epidermal growth factor receptor (EGFR) and induce G2-M cell cycle arrest. Dhanal- akshmi and others tested the protective effects of silibinin in ultraviolet radiation caused skin damages in SKH-1 hairless mice (Dhanalakshmi et al., 2004). In that study, silibinin decreased thymine dimer positive cells and increased p53-p21/Cip1 to inhibit both cell proliferation and apoptosis. Singh and others evaluated signaling pathways of silibinin's photoprotective effects in the JB6 mouse epithelial cell model (Singh et al., 2006). They found that silibinin prevents skin tumor promotion by suppressing activator protein-1 (AP-1) and NF- $\mathrm{KB}$ activation.

The results from previous studies suggest that silymarin and its components such as silibinin and isosilibinin possess strong anticancer activities such as cell growth inhibition, cell cycle arrest, and apoptosis induction. Taken together, silymarin and its components may be used as a nutraceutical or in functional foods with potential effects in cancer prevention. However, more in vivo studies are recommended to evaluate the effects of silymarin in the physiological system.

\section{Conclusions}

Silymarin is a unique herbal medicine that possesses various health beneficial effects such as antioxidant and anti-cancer activities. However, some factors should be considered when evaluating silymarin activity. The first consideration is the method used for free radical scavenging capacity. In many cases, free radical scavenging capacities are expressed as either $\%$ inhibition or halfmaximum effective concentration $\left(\mathrm{EC}_{50}\right)$. These systems are highly dependent on the reaction time and the initial concentration of free radicals and antioxidants (Xie et al., 2010). Therefore, it is important to use a standard such as Trolox and an area under the curve (AUC) for radical scavenging capacity estimation. By doing this, data between different laboratories or from the same group at different times are comparable.

The second factor to consider is the component of silymarin that is evaluated. In most cases, studies have only focused on silymarin or silymarin's component, silibinin instead of other flavonolignans. This is due to silymarin's chemical composition. In general, silibinin accounts for more than $30 \%$ of silymarin. However, several studies suggest that other flavonolignans found in silymarin or taxifolin also play an important role in health beneficial effects. For example, isosilybin A and B have shown anti-proliferative capacities against human prostate cancer $\mathrm{LNCaP}$ and $22 \mathrm{Rv} 1$ cells (Deep et al., 2007), and silydianin has shown the protective effect against reactive oxygen species (Zielinska-Przyjemska and Wiktorowicz, 2005). In addition, taxifolin has shown free radical scavenging capacities against DPPH and ABTS radicals (Topal et al., 2015). The results from these previous studies suggest that each component of silymarin exerts various health promoting effects. Therefore, in addition to silymarin or silybin, it is important to evaluate the other components. In the future, standardizing free radical scavenging capacities and evaluating each of sylimarin's components for health promoting effects such as antioxidant and anti-cancer activity will help to improve the development of nutraceuticals or functional foods.

\section{References}

Ahmad, N., Gali, H., Javed, S., and Agarwal, R. (1998). Skin cancer chemopreventive effects of a flavonoid antioxidant silymarin are mediated via impairment of receptor tyrosine kinase signaling and perturbation in cell cycle progression. Biochem. Biophys. Res. Commun. 247(2): 294-301. 
Akhtar, R., Ali, M., Mahmood, S., and Sanyal, S.N. (2014). Anti-proliferative action of silibinin on human colon adenomatous cancer HT-29 cells. Nutr. Hosp. 29(2): 388-392.

Althagafy, H.S., Meza-Aviña, M.E., Oberlies, N.H., and Croatt, M.P. (2013). Mechanistic study of the biomimetic synthesis of flavonolignan diastereoisomers in milk thistle. J. Org. Chem. 78(15): 7594-7600.

Asghar, Z., and Masood, Z. (2008). Evaluation of antioxidant properties of silymarin and its potential to inhibit peroxyl radicals in vitro. Pak. J. Pharm. Sci. 21(3): 249-254.

Babusikova, E., Evinova, A., Dobrota, D., Jurecekova, J., and Jesenak, M. (2012). Oxidative damage and bronchial asthma. In: Ghanei, M. (Ed.). Respiratory Diseases. InTech, Rijeka, Croatia, pp. 151-176.

Bendary, E., Francis, R., Ali, H., Sarwat, M., and Hady, S.E. (2013). Antioxidant and structure-activity relationships (SARs) of some phenolic and anilines compounds. Ann. Agric. Sci. 58(2): 173-181.

Bhatia, N., and Agarwal, R. (2001). Detrimental effect of cancer preventive phytochemicals silymarin, genistein and epigallocatechin 3-gallate on epigenetic events in human prostate carcinoma DU145 cells. Prostate 46(2): 98-107.

Biedermann, D., Vavř́ková, E., Cvak, L., and Křen, V. (2014). Chemistry of silybin. Nat. Prod. Rep. 31(9): 1138-1157.

Bijak, M. (2017). Silybin, a major bioactive component of milk thistle (Silybum marianum L. Gaernt.)-Chemistry, Bioavailability, and Metabolism. Molecules 22(11): 1942.

Chambers, C.S., Holečková, V., Petrásková, L., Biedermann, D., Valentová, K., Buchta, M., and Křen, V. (2017). The silymarin composition... and why does it matter??? Food Res. Int. 100: 339-353.

Chen, J., Yang, J., Ma, L., Li, J., Shahzad, N., and Kim, C.K. (2020). Structureantioxidant activity relationship of methoxy, phenolic hydroxyl, and carboxylic acid groups of phenolic acids. Sci. Rep. 10(1): 2611.

Choe, U., Li, Y., Gao, B., Yu, L., Wang, T.T., Sun, J., Chen, P., and Yu, L.L. (2019). The chemical composition of a cold-pressed milk thistle seed flour extract, and its potential health beneficial properties. Food Func. 10(5): 2461-2470.

Davis-Searles, P., Nakanishi, Y., Kim, N., Graf, T.N., Oberlies, N.H., Wani, M.C., Wall, M.E., Agarwal, R., and Kroll, D.J. (2005). Milk thistle and prostate cancer: Differential effects of pure flavonolignans from Silybum marianum on antiproliferative end points in human prostate carcinoma cells. Cancer Res. 65(10): 4448-4457.

Deep, G., Oberlies, N.H., Kroll, D.J., and Agarwal, R. (2007). Isosilybin B and isosilybin $A$ inhibit growth, induce $\mathrm{G} 1$ arrest and cause apoptosis in human prostate cancer LNCaP and 22Rv1 cells. Carcinogenesis 28(7): 1533-1542.

Dhanalakshmi, S., Agarwal, P., Glode, L.M., and Agarwal, R. (2003). Silibinin sensitizes human prostate carcinoma DU145 cells to cisplatinand carboplatin-induced growth inhibition and apoptotic death. Int. J. Cancer 106(5): 699-705.

Dhanalakshmi, S., Mallikarjuna, G.U., Singh, R.P., and Agarwal, R. (2004). Silibinin prevents ultraviolet radiation-caused skin damages in SKH-1 hairless mice via a decrease in thymine dimer positive cells and an up-regulation of p53-p21/Cip1 in epidermis. Carcinogenesis 25(8): 1459-1465.

Dhanalakshmi, S., Singh, R.P., Agarwal, C., and Agarwal, R. (2002). Silibinin inhibits constitutive and TNF $\alpha$-induced activation of NF-KB and sensitizes human prostate carcinoma DU145 cells to TNF $\alpha$-induced apoptosis. Oncogene 21(11): 1759-1767.

Eo, H.J., Park, G.H., Song, H.M., Lee, J.W., Kim, M.K., Lee, M.H., Lee, J.R., Koo, J.S., and Jeong, J.B. (2015). Silymarin induces cyclin D1 proteasomal degradation via its phosphorylation of threonine-286 in human colorectal cancer cells. Int. Immunopharmacol. 24(1): 1-6.

Fan, L., Ma, Y., Liu, Y., Zheng, D., and Huang, G. (2014). Silymarin induces cell cycle arrest and apoptosis in ovarian cancer cells. Eur. J. Pharmacol. 743: 79-88.

Federico, A., Dallio, M., and Loguercio, C. (2017). Silymarin/silybin and chronic liver disease: A marriage of many years. Molecules 22(2): 191.

Ferlay, J., Steliarova-Foucher, E., Lortet-Tieulent, J., Rosso, S., Coebergh, J., Comber, H., Forman, D., and Bray, F. (2013). Cancer incidence and mortality patterns in Europe: Estimates for 40 countries in 2012. Eur. J. Cancer 49(6): 1374-1403.

Flora, K., Hahn, M., Rosen, H., and Benner, K. (1998). Milk thistle (Silybum marianum) for the therapy of liver disease. Am. J. Gastroenterol. 93(2): 139-143.

Freedman, N.D., Silverman, D.T., Hollenbeck, A.R., Schantzkin, A., and Abnet, C.C. (2011). Association between smoking and risk of bladder cancer among men and women. Jama 306(7): 737-745.

Glaysher, S., Bolton, L.M., Johnson, P., Atkey, N., Dyson, M., Torrance, C., and Cree, I.A. (2013). Targeting EGFR and PI3K pathways in ovarian cancer. Br. J. Cancer 109(7): 1786-1794.

Halliwell, B., and Cross, C.E. (1994). Oxygen-derived species: Their relation to human disease and environmental stress. Environ. Health Perspect. 102: 5.

Hogan, F.S., Krishnegowda, N.K., Mikhailova, M., and Kahlenberg, M.S. (2007). Flavonoid, silibinin, inhibits proliferation and promotes cellcycle arrest of human coloncancer. J. Surg. Res. 143(1): 58-65.

Imai-Sumida, M., Chiyomaru, T., Majid, S., Saini, S., Nip, H., Dahiya, R., Tanaka, Y., and Yamamura, S. (2017). Silibinin suppresses bladder cancer through down-regulation of actin cytoskeleton and PI3K/Akt signaling pathways. Oncotarget 8(54): 92032-92042.

Ismaili, S.A., Marmouzi, I., Sayah, K., Harhar, H., Faouzi, M.E.A., Gharby, S., Himmi, B., Kitane, S., and Belghiti, M.A.E. (2016). Chemical analysis and anti-oxidation activities of the Moroccan Milk Thistle. Mor. J. Chem. 4(3): 695-702.

Kalla, P.K., Chitti, S., Aghamirzaei, S.T., Senthilkumar, R., and Arjunan, S. (2014). Anti-cancer activity of silymarin on MCF-7 and NCIH-23 cell lines. Adv. Biol. Res. 8(2): 57-61.

Karimi, G., Vahabzadeh, M., Lari, P., Rashedinia, M., and Moshiri, M. (2011). "Silymarin", a promising pharmacological agent for treatment of diseases. Iran. J. Basic. Med. Sci. 14(4): 308-317.

Katiyar, S.K., Korman, N.J., Mukhtar, H., and Agarwal, R. (1997). Protective effects of silymarin against photocarcinogenesis in a mouse skin model. J. Natl. Cancer I. 89(8): 556-565.

Kim, S., Choi, M., Lee, H., Lee, S., Kim, S., Kim, W., Choe, J., Nam, S., Yang, J., Lee, J., and Kim, J. (2009). Silibinin suppresses TNF- $\alpha$-induced MMP-9 expression in gastric cancer cells through inhibition of the MAPK pathway. Molecules 14(11): 4300-4311.

Kohno, H., Tanaka, T., Kawabata, K., Hirose, Y., Sugie, S., Tsuda, H., and Mori, H. (2002). Silymarin, a naturally occurring polyphenolic antioxidant flavonoid, inhibits azoxymethane-induced colon carcinogenesis in male F344 rats. Int. J. Cancer 101(5): 461-468.

Köksal, E., Gülçin, I., Beyza, S., Sarikaya, Ö., and Bursal, E. (2009). In vitro antioxidant activity of silymarin. J. of Enzym. Inhib. Med. Ch. 24(2): 395-405.

Lee, D.Y., and Liu, Y. (2003). Molecular Structure and Stereochemistry of SiIybin A, Silybin B, Isosilybin A, and Isosilybin B, Isolated fromSilybum marianum(Milk Thistle). J. Nat. Prod. 66(12): 1632-1632.

Li, L., Gao, Y., Zhang, L., Zeng, J., He, D., and Sun, Y. (2008). Silibinin inhibits cell growth and induces apoptosis by caspase activation, downregulating survivin and blocking EGFR-ERK activation in renal cell carcinoma. Cancer Lett. 272(1): 61-69.

Liang, L., Li, L., Zeng, J., Gao, J., Chen, Y., Wang, Z., Wang, X., Chang, L.S., and He, D. (2012). Inhibitory effect of silibinin on EGFR signal-induced renal cell carcinoma progression via suppression of the EGFR/MMP-9 signaling pathway. Oncol. Rep. 28(3): 999-1005.

Malekinejad, H., Rezabakhsh, A., Rahmani, F., and Hobbenaghi, R. (2012). Silymarin regulates the cytochrome $\mathrm{P} 4503 \mathrm{~A} 2$ and glutathione peroxides in the liver of streptozotocin-induced diabetic rats. Phytomedicine 19(7): 583-590.

Martin, R.J., Lauren, D.R., Smith, W.A., Jensen, D.J., Deo, B., and Douglas, J.A. (2006). Factors influencing ilymarin content and composition in variegated thistle (Silybum marianum). New Zeal. J. Crop Hort. 34(3): 239-245.

Mateen, S., Tyagi, A., Agarwal, C., Singh, R.P., and Agarwal, R. (2009). Silibinin inhibits human nonsmall cell lung cancer cell growth through cell-cycle arrest by modulating expression and function of key cellcycle regulators. Mol. Carcinog. 49(3): 247-258.

Metts, M.C., Metts, J.C., Milito, S.J., and Thomas Jr, C.R. (2000). Bladder cancer: A review of diagnosis and management. J. Natl. Med. Assoc. 92(6): 285-294.

Mhamdi, B., Abbassi, F., Smaoui, A., Abdelly, C., and Marzouk, B. (2016). Fatty acids, essential oil and phenolics composition of Silybum marianum seeds and their antioxidant activities. Pak. J. Pharm. Sci. 29(3): 
953-959.

National Institutes of Health. (2020). National Institutes of Health. Statistics at a Glance: The Burden of Cancer in the United States. https:// www.cancer.gov/about-cancer/understanding/statistics. Accessed 16 June 2020

Noh, E., Yi, M.S., Youn, H.J., Lee, B.K., Lee, Y., Han, J., Yu, H., Kim, J., and Jung, S.H. (2011). Silibinin enhances ultraviolet B-induced apoptosis in MCF-7 human breast cancer cells. J. Breast Cancer 14(1): 8

Pientaweeratch, S., Panapisal, V., and Tansirikongkol, A. (2016). Antioxidant, anti-collagenase and anti-elastase activities of Phyllanthus emblica, Manilkara zapota and silymarin: An in vitro comparative study for anti-aging applications. Pharm. Biol. 54(9): 1865-1872.

Prasad, R.R., Paudel, S., Raina, K., and Agarwal, R. (2020). Silibinin and non-melanoma skin cancers. J. Tradit. Complement. Med. In Press.

Scambia, G., Vincenzo, R.D., Ranelletti, P., Panici, P.B., Ferrandina, G., D’agostino, G., Fattorossi, A., Bombardelli, E., and Mancuso, S. (1996). Antiproliferative effect of silybin on gynaecological malignancies: Synergism with cisplatin and doxorubicin. Eur. J. Cancer 32(5): 877-882.

Shahidi, F., and Ambigaipalan, P. (2015). Phenolics and polyphenolics in foods, beverages and spices: Antioxidant activity and health effects A review. J. Funct. Foods 18: 820-897.

Sharma, G., Singh, R.P., Chan, D.C., and Agarwal, R. (2003). Silibinin induces growth inhibition and apoptotic cell death in human lung carcinoma cells. Anticancer Res. 23(3B): 2649-2655.

Sharma, Y., Agarwal, C., Singh, A.K., and Agarwal, R. (2001). Inhibitory effect of silibinin on ligand binding to erbB1 and associated mitogenic signaling, growth, and DNA synthesis in advanced human prostate carcinoma cells. Mol. Carcinog. 30(4): 224-236.

Singh, R.P., Dhanalakshmi, S., Mohan, S., Agarwal, C., and Agarwal, R. (2006). Silibinin inhibits UVB- and epidermal growth factor-induced mitogenic and cell survival signaling involving activator protein-1 and nuclear factor-KB in mouse epidermal JB6 cells. Mol. Cancer Ther. 5(5): 1145-1153.

Singh, R.P., Dhanalakshmi, S., Tyagi, A.K., Chan, D.C.F., Agarwal, C., and Agarwal, R. (2002). Dietary feeding of silibinin inhibits advance human prostate carcinoma growth in athymic nude mice and increases plasma insulin-like growth factor-binding protein-3 levels. Cancer Res. 62(11): 3063-3069.

Singh, R., Sharma, G., Dhanalakshmi, S., Agarwal, C., and Agarwal, R. (2003). Suppression of advanced human prostate tumor growth in athymic mice by silibinin feeding is associated with reduced cell proliferation, increased apoptosis, and inhibition of angiogenesis. Cancer Epidemiol. Biomarkers Prev. 12(9): 933-939.

Singh, T., Prasad, R., and Katiyar, S.K. (2016). Therapeutic intervention of silymarin on the migration of non-small cell lung cancer cells is associated with the axis of multiple molecular targets including class 1 HDACs, ZEB1 expression, and restoration of miR-203 and E-cadherin Expression. Am. J. Cancer Res. 6(6): 1287-1301.

Sun, Y., Guan, Z., Zhao, W., Jiang, Y., Li, Q., Cheng, Y., and Xu, Y. (2017). Silibinin suppresses bladder cancer cell malignancy and chemoresistance in an NF-KB signal-dependent and signal-independent manner. Int. J. Oncol. 51(4): 1219-1226.

Topal, F., Nar, M., Gocer, H., Kalin, P., Kocyigit, U.M., Gülçin, I., and Alwasel, S.H. (2015). Antioxidant activity of taxifolin: An activity-structure relationship. J. Enzym. Inhibit. Med. Ch. 31(4): 674-683.

Ttagi, A., Singh, R.P., Agarwal, C., Chan, D.C.F., and Agarwal, R. (2007). Silibinin strongly synergizes human prostate carcinoma DU145 cells to doxorubicin-induced growth inhibition, G2-M arrest, and apoptosis.
Clin. Cancer Res. 8(11): 3512-3519.

Tupe, R.S., Kemse, N.G., and Khaire, A.A. (2013). Evaluation of antioxidant potentials and total phenolic contents of selected Indian herbs powder extracts. Int. Food Res. J. 20(3): 1053-1063.

Tyagi, A., Raina, K., Singh, R.P., Gu, M., Agarwal, C., Harrison, G., Glode, L.M., and Agarwal, R. (2007). Chemopreventive effects of silymarin and silibinin on $\mathrm{N}$-butyl-N-(4-hydroxybutyl) nitrosamine induced urinary bladder carcinogenesis in male ICR mice. Mol. Cancer Ther. 6(12): 3248-3255.

Wang, Y., Cai, H., Jiang, G., Zhou, T., and Wu, H. (2014). Silibinin inhibits proliferation, induces apoptosis and causes cell cycle arrest in human gastric cancer MGC803 cells via STAT3 pathway inhibition. Asian Pac. J. Cancer P. 15(16): 6791-6798.

Watters, J.L., Park, Y., Hollenbeck, A., Schatzkin, A., and Albanes, D. (2009). Cigarette smoking and prostate cancer in a prospective US cohort study. Cancer Epidemiol. Biomarkers Prev. 18(9): 2427-2435.

Willcox, J.K., Ash, S.L., and Catignani, G.L. (2004). Antioxidants and prevention of chronic disease. Crit. Rev. Food Sci. Nutr 44(4): 275-295.

Won, D., Kim, L., Jang, B., Yang, I., Kwon, H., Jin, B., Oh, S.H., Kang, J., Hong, S., Shin, J., and Cho, S. (2018). In vitro and in vivo anti-cancer activity of silymarin on oral cancer. Tumor Biol 40(5): 101042831877617.

World Health Organization. (2020). World Health Organization. Key facts. https://www.who.int/news-room/fact-sheets/detail/cancer. Accessed 25 June 2020.

Wu, K., Zeng, J., Li, L., Fan, J., Zhang, D., Xue, Y., Zhu, G., Yang, L., Wang, X., and $\mathrm{He}, \mathrm{D}$. (2010). Silibinin reverses epithelial-to-mesenchymal transition in metastatic prostate cancer cells by targeting transcription factors. Oncol. Rep. 23(6): 1545-1552.

Xie, Z., Liu, W., Huang, H., Slavin, M., Zhao, Y., Whent, M., Blackford, J., Lutterodt, H., Zhou, H., Chen, P., Wang, T.T.Y., Wang, S., and Yu, L.L. (2010). Chemical composition of five commercial Gynostemma pentaphyllum samples and their radical scavenging, antiproliferative, and antiinflammatory properties. J. Agric. Food Chem. 58(21): 11243-11249.

Zappa, C., and Mousa, S.A. (2016). Non-small cell lung cancer: Current treatment and future advances. Transl. Lung Cancer R. 5(3): 288-300.

Zhu, W. (2001). Silymarin inhibits function of the androgen receptor by reducing nuclear localization of the receptor in the human prostate cancer cell line LNCaP. Carcinogenesis 22(9): 1399-1403.

$\mathrm{Zi}, \mathrm{X}$., and Agarwal, R. (1999). Silibinin decreases prostate-specific antigen with cell growth inhibition via G1 arrest, leading to differentiation of prostate carcinoma cells: Implications for prostate cancer intervention. Proc. Natl. Acad. Sci. U. S. A. 96(13): 7490-7495.

Zi, X., Feyes, D.K., and Agarwal, R. (1998). Anticarcinogenic effect of a flavonoid antioxidant, silymarin, in human breast cancer cells MDA-MB 468: Induction of G1 arrest through an increase in Cip1/p21 concomitant with a decrease in kinase activity of cyclin-dependent kinases and associated cyclins. Clin. Cancer. Res. 4(4): 1055-1064.

Zi, X., Grasso, A.W., Kung, H.J., and Agarwal, R. (1998). A flavonoid antioxidant, silymarin, inhibits activation of erbB1 signaling and induces cyclin-dependent kinase inhibitors, G1 arrest, and anticarcinogenic effects in human prostate carcinoma DU145 cells. Cancer Res. 58(9): 1920-1929.

Zi, X., Zhang, J., Agarwal, R., and Pollak, M. (2000). Silibinin up-regulates insulin-like growth factor-binding protein 3 expression and inhibits proliferation of androgen-independent prostate cancer cells. Cancer Res. 60(20): 5617-5620.

Zielińska-Przyjemska, M., and Wiktorowicz, K. (2006). An in vitro study of the protective effect of the flavonoid silydianin against reactive oxygen species. Phytother Res. 20(2): 115-119. 